\title{
Nobody can Really Afford Legal Services: \\ The Price of Justice in Namibia
}

\section{P.E.R}

Pioneer in peer-reviewed, open access online law publications

Author

Dunia Zongwe

\section{Affiliation}

Walter Sisulu University

South Africa

Email

\section{dzongwe@wsu.ac.za}

Date Submission

30 May 2019

Date Revised

18 May 2021

Date Accepted

18 May 2021

Date published

25 May 2021

\section{Editor Prof C Rautenbach}

How to cite this article

Zongwe DP "Nobody can Really Afford Legal Services: The Price of Justice in Namibia" PER / PELJ 2021(24) - DOI

http://dx.doi.org/10.17159/17273781/2021/v24i0a6420

\section{Copyright}

DOI

http://dx.doi.org/10.17159/1727$3781 / 2021 / v 24 i 0 a 6420$

\begin{abstract}
Nobody (except for the privileged few) can afford legal services in Namibia. In the light of this dawning awareness, how should the government and other stakeholders design the legal profession so that the greatest number of Namibians can access legal services and, ultimately, justice while preserving the profession's financial viability? The predominantly economic nature of this question means that its solutions lie less in the field of law than in the field of economics. Thus, this article adopts a methodology that reflects that insight.
\end{abstract}

As a primary purpose, this article works towards solving the high cost of legal services in Namibia. It utilises a literature-review methodology that searches the scholarship on the legal profession for practical, down-to-earth solutions put forward in other countries to take the edge off the prohibitive cost of legal services. The article mainly finds that, if structured as a compulsory salary deduction, legal insurance promises the greatest positive impact on costs. And it concludes that the optimal solutions should consist of measures aimed at heightening competition in the legal profession and measures that broaden cost-sharing in providing legal assistance to the public. The article argues that competition can be effectively increased by lubricating the flow of information about prices and services, and by having more public entities bear the burden of expanding the system of legal assistance.

\section{Keywords}

Legal services; unaffordability; Namibia; insurance; poverty; inaccessibility. 


\section{Introduction}

Since March 1990 the Constitution of Namibia has promised access to justice ${ }^{1}$ and justice for all, ${ }^{2}$ yet this idealised and bright outlook for Namibian society feels like a distant dream today. Women, in particular, have to struggle uphill to access justice. Assuming that an average lawyer in solo practice bills his clients $\mathrm{N} \$ 700$ per hour, ${ }^{3}$ the average Namibian will afford only one hour of legal services per week. ${ }^{4}$ (Namibia has pegged its currency, the Namibian dollar, one-to-one to the South African Rand.) ${ }^{5}$ These statistics, however rough, point to an alarming yet inescapable truth: Nobody (except for the privileged few) can afford legal services. To the countless, faceless Namibians who desperately and vainly seek legal advice every day, the constitutional promise of justice and justice for all sounds meaningless and cruelly cynical.

How should the government and other stakeholders design the legal profession so as to make legal services and, ultimately, justice accessible to the greatest number of Namibians while preserving the profession's financial viability? From the outset, this article posits that the huge cost of legal services presents a question that is eminently economic in nature. The predominantly economic nature of the problem means that its solutions lie

Dunia P Zongwe. Associate Professor and Head of the Mercantile Law Unit, Walter Sisulu University, South Africa. JSD (Cornell); LLM (Cornell); Cert (University of Montréal); LLB (University of Namibia); BJuris (University of Namibia). E-mail: dzongwe@wsu.ac.za. ORCID number: 0000-0003-2849-5351. From December 2016 to April 2018, I have consulted for the Law Society of Namibia (LSN) on its Change Project, regarding the relevance of the legal profession in Namibia. I warmly thank François-Xavier Bangamwabo, Phillip Balhao, J Jarpa Dawuni, Eben de Klerk, Lizazi Libebe, Ramon Maasdorp, Ndjodi Ndeunyema, Leezola R Zongwe, and an anonymous reviewer for their constructive and invaluable comments on an earlier version of this work. The views expressed in this article are mine alone and do not necessarily reflect the views of the LSN or the people who commented on the article. On 28 May 2020, I presented a draft of this work at the Law and Society Association's virtual Annual Meeting, entitled "Rule and Resistance" held in Denver, USA. I thank Mark Fathi Massoud, Misha Plagis, and David B Wilkins for sharing their impressions of my presentation. I am solely responsible for errors or shortcomings, if any, in this article.

Preamble of the Constitution of Namibia, 1990 (hereafter the Constitution).

Article 1(1) of the Constitution.

See Klaaren 2014 The Salon 21.

Further assuming that the average monthly income in Namibia is $N \$ 4,814$ (based on statistics presented later in this article) and that the average person will not spend more than half of his weekly income on legal services.

5 Namibia belongs to the Common Monetary Area (CMA), an arrangement in terms of which Namibia, Lesotho, and eSwatini (ie, Swaziland) operate a fixed peg against the South African rand, without restricting capital flow. Bank of Namibia Challenges of Monetary Policy 4. Also see Zongwe "Legal Significance of the Euro Crisis" 80-83 (explaining the CMA and its currency peg). 
less in the field of law than in the field of economics. Thus, this article adopts a methodology that reflects that insight. The author has basically structured it as a full-length, stand-alone piece that reviews the literature on the costs of legal services.

This article strives to solve the relative unaffordability of legal services in Namibia. It proceeds in four logical steps. The first one looks at the law as a model for settling disputes and as an essential element of any functioning society. It also offers a bird's-eye view of the legal profession in Namibia. Second, the article dissects the unaffordability of legal services in Namibia. The next step searches the scholarship on the legal profession for practical, down-to-earth solutions put forward in other jurisdictions to take the edge off the prohibitive cost of legal services.

Nevertheless, while the chosen methodology (i.e. a literature review) excels at discovering areas with immense potential for unravelling society's conundrums, ${ }^{6}$ it seldom resolves them. Still, literature reviews do a fantastic job in suggesting those fruitful research areas. By the same token, the literature surveyed in this article points to legal insurance as fodder for further useful research.

Last step, the article suggests a set of policy choices that Namibia can carry out in order to lessen the acute dilemma of unaffordable legal services. Optimal solutions should consist of measures aimed at heightening competition in the legal profession and measures that broaden cost-sharing in providing legal assistance to the public. This article mainly argues that competition can be effectively increased by lubricating the flow of information about prices and services, and by having more public entities bear the burden of expanding the system of legal assistance. In this manner, policy makers would drive down the cost of legal services and ensure, at the same time, that the legal profession remains profitable and attractive to the brightest Namibians.

\section{The law as an essential function of society}

Prohibitive costs, including the difficulty of accessing the courts, do not affect Namibia only. For instance, in the United States of America (US) the

$6 \quad$ See Snyder $2019 \mathrm{~J}$ Bus Res 339 (observing that literature reviews serve as the foundation for all types of research because they help develop knowledge, guide policy and practice, adduce evidence of an effect, and - if well executed - engender new ideas and directions for a particular field); and Boote and Beile Educ Res 3 (positing that a thorough literature review underpins and inspires useful research). 
poor account for about $13 \%$ of the population, ${ }^{7}$ and $80 \%$ of the poor have no means of accessing the courts. ${ }^{8}$ This situation should cause public alarm because the affordability of legal services conditions access to justice, one of the core functions of any legal system and a paramount aspect of the administration of justice.

\subsection{Law and the dispute-settling function}

Societies cannot dispense with law, taken in its broader sense. It is almost inconceivable to have justice without a well-established body of rules and principles to regulate the behaviour of people in society. As Alexander Hamilton famously said, "[t]he first duty of society is justice".

Particularly, the law's function in resolving disputes features any full-blown legal system. HLA Hart brought this point home when he said that the "rule of adjudication" characterises mature legal systems. ${ }^{9}$ According to renowned US judge Oliver Holmes, the dispute-resolution function explains why law is a profession: ${ }^{10}$

The reason why it is a profession, why people will pay lawyers to argue for them or to advise them, is that in societies like ours the command of the public force is intrusted to the judges in certain cases, and the whole power of the state will be put forth, if necessary, to carry out their judgments and decrees.

Fundamentally, justice cannot triumph in the absence of proper legal representation in court. The Supreme Court of Namibia has even made it a procedural irregularity when a judge forgets to inform an accused of his right to such representation. ${ }^{11}$ Without enough money, litigants cannot secure legal representation; without representation, justice will elude the litigants. The inability of an unrepresented litigant to prepare pleadings, thoroughly investigate, navigate through the rules of evidence, identify the rules that apply to his case, and eventually argue the case before judges make efforts to achieve justice futile. ${ }^{12}$ On the other hand, involving lawyers in a dispute may muddle or complicate its resolution.

\footnotetext{
Semega et al Income and Poverty in the United States 60-259.

ABA Report on the Future of Legal Services iii.

Hart Concept of Law 92ff.

Holmes 1897 Harv L Rev 457-478.

State $v$ Kau 1995 NR 1 (SC).

Also see Morris Leadership on the Federal Bench 196 (quoting Jack Weinstein, who remarked that the preparation of pleadings, the conduct of investigations, the rules of evidence, the necessity to carry out legal research, and the rigour of trial advocacy make the fair disposition of most civil litigation almost impossible).
} 


\subsection{Justice for all and access to justice}

The importance of reflecting on the costs involved in seeking the advice of legal professionals and in litigating claims cannot be overemphasised. The whole question of access to justice crucially pivots on those costs. ${ }^{13} \mathrm{~A}$ survey conducted by the Office of the Ombudsman bears this out - a survey in which most respondents cited court-related costs as barring access to justice. $^{14}$

Through the preamble of the Constitution, the Namibian people have "constitute[d] the Republic of Namibia as a sovereign, secular, democratic and unitary State securing to all citizens justice, liberty, equality and fraternity"..$^{15}$ And in its very first article, the Constitution stresses this point: ${ }^{16}$

The Republic of Namibia is hereby established as a sovereign, secular, democratic and unitary State founded upon the principles of democracy, the rule of law and justice for all.

Further underlining this position, Article 30 of the Constitution requires every newly elected President to make the following oath when the Chief Justice swears him or her into office: ${ }^{17}$

I... do hereby swear [or] solemnly affirm... [t]hat I will endeavour to the best of my ability to ensure justice for all the inhabitants of the Republic of Namibia.

The principle of "justice for all" is complemented by constitutional guarantees that people may approach the courts and vindicate their rights, as provided for in Article 25 (enforcement of rights and freedoms) and Article 18 (administrative justice). ${ }^{18}$ According to Article 25:

(2) Aggrieved persons who claim that a fundamental right or freedom guaranteed by this Constitution has been infringed or threatened shall be entitled to approach a competent Court to enforce or protect such a right or freedom, and may approach the Ombudsman to provide them with such legal assistance or advice as they require .... .

13 See Lee U Miami L Rev 500 (framing the issue of access to justice as depending on litigation costs).

14 Office of the Ombudsman 2013 Baseline Study Report on Human Rights 122.

15 Emphasis added.

16 Article 1(1) of the Constitution. Emphasis added.

17 Emphasis added.

18 Article 18 of the Constitution. Article 18 lays down that "[a]dministrative bodies and administrative officials shall act fairly and reasonably and comply with the requirements imposed upon such bodies and officials by common law and any relevant legislation, and persons aggrieved by the exercise of such acts and decisions shall have the right to seek redress before a competent Court or Tribunal." 
(3)

... the Court referred to in Sub Article (2) hereof shall have the power to make all such orders as shall be necessary and appropriate to secure such applicants the enjoyment of the rights and freedoms conferred on them under the provisions of this Constitution, should the Court come to the conclusion that such rights or freedoms have been unlawfully denied or violated, or that grounds exist for the protection of such rights or freedoms by interdict.

Moreover, the Universal Declaration of Human Rights, ${ }^{19}$ the International Covenant on Civil and Political Rights (ICCPR), ${ }^{20}$ and the African Charter on Human and Peoples' Rights (the "Banjul Charter") ${ }^{21}$ all guarantee access to justice. And, by virtue of Article 144, ${ }^{22}$ those international treaties form part of Namibian law. ${ }^{23}$ As US judge Hobbs Jr. enthused, access to justice is "the single most compelling reason for a legal profession". ${ }^{24}$

\subsection{The legal profession in Namibia}

The term "legal profession" has strict and broad senses. Strictly speaking, "legal profession" encompasses all the legally trained people formally admitted to practice in the courts of Namibia. This group of people is often and formally referred to as "legal practitioners". The Legal Practitioners Act 15 of 1995 defines a "legal practitioner" as "a person who ... has been

19 See art 7 of the Universal Declaration of Human Rights (1948) (UDHR): "All are equal before the law and are entitled without any discrimination to equal protection of the law..." Also see art 8 of the UDHR: "Everyone has the right to an effective remedy by the competent national tribunals for acts violating the fundamental rights granted him by the constitution or by law." Article 14 of the International Covenant on Civil and Political Rights (1966) (ICCPR). Article 3(2) of the African Charter on Human and Peoples' Rights (1981) (the "Banjul Charter"): "Every individual shall be entitled to equal protection of the law."

Article 144 of the Constitution serves as the constitutional basis for the application of international law in Namibia and makes international law one of the formal sources of Namibian law. Specifically, art 144 stipulates that "[u]nless otherwise provided by this Constitution or Act of Parliament, the general rules of public international law and international agreements binding upon Namibia under this Constitution shall form part of the law of Namibia."

For more information on how international law applies in Namibia, see Zongwe International Law in Namibia. Note, however, that the UDHR does not constitute an international treaty. All the same, judges and lawyers in Namibia could possibly apply the Declaration through interpretation. See Kauesa v Minister of Home Affairs 1994 NR 102 (HC) 140 (where the High Court held that "it is unquestionable that whether the framework for the Namibian Constitution prescribed for the Constituent Assembly and the Constitution for an independent Namibia in the so-called '1982 Constitutional Principles' and the Universal Declaration of Human Rights have become part of the law of Namibia"). But, because the Supreme Court in Kauesa v Minister of Home Affairs and Others 1995 NR 175 (SC) reversed the High Court judgement, though on a ground other than the High Court's holding on the UDHR, one could question or challenge the status of the Universal Declaration in Namibia's legal system. Hobbs 2012 Denv U L Rev 851. 
admitted and authorised to practise as a legal practitioner or is deemed to have been so admitted and authorised." 25

Understood in the wider sense, the "legal profession" refers to persons who either directly, indirectly or remotely perform legal services. This group comprises educational institutions such as the University of Namibia; government institutions like the Ministry of Justice, the Ombudsman, the Attorney-General, and the Anti-Corruption Commission; and civil society organisations like the Legal Assistance Centre.

This article focusses on the legal profession in the strict sense, and not in the broad sense of that expression. That is, for the purposes of this article, the term "legal profession" means legal practitioners taken as a whole, or the group of people admitted to practice in Namibia.

Currently Namibia has about 700 legal practitioners. They enjoy a stateenforced monopoly in offering a wide array of legal services. Prominent examples of these services include conveyancing, divorce, and wills (or succession). ${ }^{26}$

The legal profession and the services they render are both regulated by the government and self-regulated by the Law Society of Namibia. The Law Society of Namibia (LSN) stands out from its counterparts in other countries insofar as it legally acts as both the regulator and the representative association of the legal profession. These two roles appear to be mutually exclusive: How can an institution regulate a profession and at the same time defend the interests, including pushing the agenda, of the self-same profession? This situation has led some to say that the LSN faces a conflict of interests. For instance, would the LSN enforce regulations aimed at keeping legal fees at a low level for the general public while at the same time lobbying for the interests of its members who would want to increase their fees? No evidence exists that the LSN is conflicted, but this situation makes the LSN look so compromised.

\section{The costs of legal services in Namibia}

\subsection{Are legal services in Namibia really unaffordable?}

How does one determine "unaffordability"? While there is no generally accepted threshold of affordability, the Oxford Dictionary defines

25 Section 1 of the Legal Practitioners Act 15 of 1995, sv "legal practitioner".

26 See OMB Research Prices of Individual Consumer Legal Services 3. 
"unaffordable" as "too expensive to be afforded by the average person". ${ }^{27}$ Based on that definition, legal services in Namibia are really unaffordable as the average person does not have the financial means to pay for them. And the average woman earns less than the average man, ${ }^{28}$ suggesting that women struggle more than men to access those services.

Still, when compared to other professions in Namibia, law does not entail significantly higher fees. This conclusion flows from the findings of a small survey of professional fees conducted in 2017 in Windhoek on behalf of the LSN (hereinafter the "LSN Survey"). ${ }^{29}$ A first-year accountant earns between $\mathrm{N} \$ 800$ and $\mathrm{N} \$ 900$ per hour ${ }^{30}$ while a first-year legal practitioner earns in the vicinity of $\mathrm{N} \$ 700$ per hour. By contrast, in the medical profession, a general practitioner bills his or her clients around $\mathrm{N} \$ 2,100$ per hour and a specialist around $\mathrm{N} \$ 2,300$ per hour. ${ }^{31}$

Nonetheless, whether lawyers charge lower or higher fees than those charged in professions such as medicine and auditing does not change the reality that the great majority of Namibians cannot afford legal services.

\subsection{The lie of the land}

Hardly anything has been written on access to justice and the cost of legal services in Namibia. The same holds for research on the obstacles women face in accessing justice. The Office of the Ombudsman published a report on access to justice in Namibia ${ }^{32}$ and collaborated with Afrobarometer in 2017 on the same topic, albeit from a continental perspective. ${ }^{33}$ Publications of this sort remain few and far between.

But elsewhere, scholars have acknowledged that most access-to-justice efforts centre on bridging the "justice gap". ${ }^{34}$ They further recognise that legal professions across the globe and the delivery of legal services are

\footnotetext{
27 Oxford Dictionaries 2018 https://en.oxforddictionaries.com/definition/unaffordable, sv "unaffordable". NSA Namibia Labour Force Survey 20147. Law Society of Namibia LSN Survey of Professional Fees 31 October 2017 (hereafter LSN Survey) (on file with the author). I carried out that small survey as a consultant on behalf of the LSN.

LSN Survey.

LSN Survey.

Office of the Ombudsman 2013 Baseline Study Report on Human Rights 121-127. Logan https://media.africaportal.org/documents/ab_r6_policypaperno39_access_to_justic e_in_africa_eng.pdf 38. Woolley and Farrow 2016 Texas A\&M L Rev 550.
} 
undergoing epoch-making changes ${ }^{35}$ - changes that also affect how much legal services cost and how lawyers sell them.

In trying to access those services, women grapple with unique stumbling blocks. All over the world, they must overcome big hurdles as they face several sorts of discrimination due to their ethnicity, gender, and class. ${ }^{36}$

As to legal costs, no on one has published anything on that specific topic. The LSN wrote a report that discusses costs, but it does not focus on them systematically, nor does it address them in great depth. Thus, this gap leaves most people in the dark about the contours and precise details of the cost of legal services in Namibia. Yet this is a burning issue as it adversely affects Namibians on a daily basis.

\subsection{A few vital statistics}

A few statistics reveal that the greatest part of the population cannot foot legal fees, especially in civil matters. The average monthly income in Namibia hovers around $\mathrm{N} \$ 4,814$ Namibian dollars ${ }^{37}$ while the average monthly salary is about $\mathrm{N} \$ 7,935 .{ }^{38}$

This average income puts Namibia in the enviable "upper middle-income" category, but it masks glaring income disparities between rich and poor. As a matter of fact, Namibia ranks as one of the world's most unequal societies. With a Gini coefficient of $60 \%,{ }^{39}$ the majority of Namibians earn much less than $\mathrm{N} \$ 4,814$ per month. A charitable interpretation of Namibia's Gini

See Hill 2017 Or Rev Int'l L 135-184; Woolley and Farrow 2016 Texas A\&M L Rev 550; and Dzienkowski 2014 Fordham L Rev 2995-3040. Sieder and Sierra 2010 https://www.cmi.no/publications/file/3880-indigenouswomens-access-to-justice-in-latin.pdf 1.

The average annual personal income in Namibia is 4,640 US dollars, as determined by the gross national income (GNI) per capita: World Bank 2018 https://data.worldbank.org/country/namibia. In Namibian dollars or South African rands, this amount equalled 57,762, as of April 2018. On a monthly basis, the average income is $\mathrm{N} \$ 4813.5$ (= 57762 / 12).

See NSA Namibia Labour Force Survey 2018 67-68 (reporting that the average wage or salary in Namibia is $\mathrm{N} \$ 7,935$ per month). Also see NSA Namibia Labour Force Survey 201650 (reporting that the average wage or salary in Namibia is $\mathrm{N} \$ 6,759$ ) and NSA Namibia Labour Force Survey $201463 \mathrm{ff}$ (reporting that the average wage or salary in Namibia is $\mathrm{N} \$ 6,626)$.

This rate is only an estimate. It reflects data from the World Bank and the Namibian government. See World Bank 2018 https://data.worldbank.org/indicator/ SI.POV.GINI? locations=NA (indicating that Namibia's Gini coefficient was $61 \%$ as of 2009). Also see Staff Reporter 2017 https://neweralive.na/posts/namibia-reducespoverty-levels-despite-economic-challenges (reporting statements by Finance Minister Calle Schlettwein, who said that Namibia's Gini coefficient stood at 57,2\% according to preliminary results for the $2015 / 2016$ financial year). 
coefficient is that $10 \%$ of the population earns $70 \%$ of the annual national income; 40 a pessimistic reading of that index holds that $20 \%$ of the population earns $80 \% .{ }^{41}$ Either way, the picture that emerges does not show anything rosy.

In view of Namibia's gross national income (GNI) of 11,5 billion US dollars, ${ }^{42}$ the above figures imply that 247,971 people (i.e. $10 \%$ of the population) earn 8 billion US dollars annually (i.e. $70 \%$ of the GNI) ${ }^{43}$ and $671,175,652$ US dollars per month. ${ }^{44}$ By contrast, 2,2 million people (i.e. $90 \%$ of the population) ${ }^{45}$ earn 2.3 billion US dollars annually (i.e. $20 \%$ of the GNI ${ }^{46}$ and $191,764,472$ US dollars per month. ${ }^{47}$ These figures in US dollars, when converted to Namibian dollars or South African Rands, reveal that $90 \%$ of the population earns 2.4 billion Namibian dollars per month. ${ }^{48}$ In other words, the overwhelming majority of Namibians earns on average a meagre 970 Namibian dollars per month. ${ }^{49}$ From these arithmetic operations, it is clear as day that nine Namibians out of ten cannot afford legal services.

Just as evidently, nine out of ten Namibians can barely afford one hour of legal services per month by a junior legal practitioner. (The average price for legal services by a lawyer with three years' experience can hover around $\mathrm{N} \$ 1,200$ per hour ${ }^{50}$ while a seasoned and established lawyer can charge as high as $\mathrm{N} \$ 2,000$ per hour.) This amount of legal care will never do if a client requires a lawyer to do more than simply tell him or her what rules apply to his or her case. And, often, clients want their lawyers to draft contracts, write wills, prepare conveyancing documents, and so on. In other words, most clients would want their lawyers to go beyond mere legal advice and

$40 \quad 60 \%(=70-10)$.

41 In a worst-case scenario, a $60 \%$ Gini coefficient means that $20 \%$ of the population earns $80 \%$ of the annual national income.

$4211,505,868,320$ = gross national income $(\mathrm{GNI})$ per capita (ie, U\$4,640 in 2016) multiplied by the total population (ie, 2,479,713 in 2016). World Bank 2018 https://data.worldbank.org/country/namibia. As of April 2018, 1 US dollar fetched 12.45 Namibian dollars or South African rands.

$43 \quad 8,054,107,824=11,505,868,302 \times 70 \%$.

$4470 \%$ of GNI (ie, $8,054,107,824$ ) divided by 12 months.

$45 \quad 2,231,741.7=2,479,713 \times 90 \%$.

$46 \quad 2,301,173,664=11,505,868,302 \times 20 \%$.

$47 \quad 20 \%$ of GNI (ie, 2,301,173,664) divided by 12 months.

48 Exactly $2,404,179,950.13$ Namibian dollars or South African rands.

49 The average monthly income of people in Namibia is exactly 969.53 (= $2,404,179,950.13$ / 2,479,713). Also see Jauch and Tjirera "Need for Developmental State Intervention" 166 (stating that per-capita annual incomes in Namibia ranges from $\mathrm{N} \$ 2,085$ in the lowest decile - accounting for $15.9 \%$ of the population - to $\mathrm{N} \$ 230,616$ amongst the wealthiest $1.1 \%$ ). LSN Survey. 
therefore need more than one hour of legal services per month when a complex legal issue arises.

Likewise, if compared to the average salary or income, the average cost of litigation or legal services unearths a similarly gloomy picture. In 2016 the High Court of Namibia estimated that the average litigation costs for a defended High Court action ranges from 50,000 to 100,000 per litigant, if represented. ${ }^{51}$ Earlier in 2015 the Chief Registrar of the High Court, Elsie Schickerling, said that the average litigation costs in defended High Court actions amount to about $\mathrm{N} \$ 100000$ to $\mathrm{N} \$ 150000$ per litigant if represented by a lawyer, which would result in total legal costs of $N \$ 200000$ to $N \$ 300$ 000 for the parties involved in an average civil case in the High Court. ${ }^{52}$ These figures say that too few Namibians can afford to pursue their grievances in court.

With reference to the situation of women, the Namibia Statistics Agency (NSA) showed that, in 2014, women earned monthly median wages of $\mathrm{N} \$ 6,125$ whereas men pocketed monthly median wages of $\mathrm{N} \$ 7,315$. $^{53}$ And in 2018 the NSA indicated that, while slightly more women (i.e. 364,234) are employed than men (i.e. 361,508$)$, more men $(50.9 \%)$ worked in urban areas than women (49.1\%), most of whom worked in rural areas (51.7\%). ${ }^{54}$ These data clearly show that women do not have the financial means that men possess to pay for the services of a lawyer or to pursue their grievances in court.

\section{The central issues}

\subsection{Incomplete information: The heart of the problem}

Crucially, very little is known about the actual costs of delivering legal services, while multiple factors seem to cause those costs. Experts have only rough estimates. Unless a market is centralised, no one knows the prices which buyers and sellers quote at any given time. ${ }^{55}$

This knowledge gap concerns policy makers the world over. Most lawyers do not know, nor are they able to compute, the actual economic costs of the services they render. Lawyers also labour to tell in advance how much their

\footnotetext{
$51 \quad$ High Court of Namibia Annual Report 2015-16 18.

52 Menges 2015 https://www.namibian.com.na/134524/archive-read/Mediationsaving-money-and-court-time.

$53 \quad$ NSA Namibia Labour Force Survey 20147.

$54 \quad$ NSA Namibia Labour Force Survey 201855.

$55 \quad$ Stigler $1961 \mathrm{~J}$ Polit Econ 213.
} 
services will cost, especially in the case of court litigation. This limited knowledge and ability explains in part why lawyers stubbornly persist in using the billable hour model. Even if this model keeps consumers away. ${ }^{56}$

Basically, two institutions set the prices (or costs) for legal services: the state and the market. Before the decision by the Namibian Competition Commission ( $\mathrm{NaCC}$ ) in 2015, the LSN (the state) largely determined legal fees. ${ }^{57}$ After the NaCC's decision, however, the market now fixes and adjusts the fees.

Nevertheless, the NaCC's market-friendly position has not settled the question. In academia, scholars have put forth several frameworks for determining legal costs. For instance, the Law and Development Partnership designed a five-step methodology to calculate the unit cost of legal services. ${ }^{58}$ Emery Lee built a compelling general framework for the notion of legal services unaffordability. He identifies cost, speed, and justice as goals; and he studies how they interact and - in most cases - conflict. ${ }^{59}$

At the end of the day, the lack of information still haunts the debate on the value of legal services. Parties will find it difficult to assess the efficient price of legal services if neither the demand for nor the supply of those services is known. Ideally, the price of a resource depends on its relative scarcity. Scarcity in turn expresses strong demand compared to supply. To put it simply, parties will have to try really hard to determine the value of legal services if they cannot ascertain their scarcity. To compound matters, people do not always know when they need legal services and therefore when they should demand them. Research in Australia shows that many people do not even know that the problems they confront are legal in nature. ${ }^{60}$

\subsection{Why this proves a difficult problem}

Why do legal services cost a lot? The Australian organization Centre for Innovative Justice thinks that the problem is not one of supply. ${ }^{61}$ Other factors directly influence the high cost of those services.

\footnotetext{
$56 \quad$ See Centre for Innovative Justice Affordable Justice 4.

57 GN 564 in GG 5906 of 23 December 2015.

$58 \quad$ Law and Development Partnership Developing a Portfolio.

$59 \quad$ Lee 2015 U Miami L Rev 499.

$60 \quad$ Centre for Innovative Justice Affordable Justice 9.

61 Centre for Innovative Justice Affordable Justice 9.
} 


\subsubsection{The tyranny of the billable hour}

One major complicating factor is the "tyranny of the billable hour". An increasing number within and outside the profession has acknowledged the tyranny of the time-based billing model, which is criticised as discouraging efficiency and collaboration; encouraging procrastination and mediocrity; preventing any concerted investment in other approaches; and demoralising legal practitioners. ${ }^{62}$

Accordingly, some have proposed to get rid of this model. ${ }^{63}$ However, for these propositions to resolve the unaffordability of legal services successfully, they must bridge the information gap that forms the heart of this problem. Without information on how best to price legal services, replacing the hourly billing model will not do much to resolve the affordability problem.

\subsubsection{An overstretched state}

Most solutions employed to address legal costs and most of those discussed in this article ultimately need the state as a key player. Maintaining the court system; providing legal aid; initiating public prosecutions; setting up small claims courts; increasing the number of regulators, including the competition commission; and subsidising the public provision of legal services such as the legal assistance lent by the Ombudsman - all these aspects of a proper response to high legal costs require the involvement of the state. Society cannot do without the state in tackling legal costs.

In Namibia, particularly, the state is overstretched. The state takes too much space in the economy, ${ }^{64}$ with little room for the private sector to mobilise resources for rendering legal services to the public. Inexorably, the state has, as a consequence, over-stretched itself, unable alone to extend those services free of charge or at a substantially reduced price to the greatest number of its citizens.

\footnotetext{
Centre for Innovative Justice Affordable Justice 11.

For instance, Centre for Innovative Justice Affordable Justice 5.

See Mwinga et al Namibia Fiscal Policy Analysis 7 (estimating that government expenditure as a percentage of gross domestic product (GDP) averaged 32.7 over the past 29 years) and Editor 2019 https://www.namibian.com.na/186617/archiveread/Stop-The-SOE-Madness-FOR-the-better-part-of (reporting that parastatals in Namibia grew from 12 in 1990 to more than 300 by December 2017).
} 
This is a vitally important issue. In fact, this article identifies an overburdened state as lying at the root of the exorbitant cost of legal services in the country, alongside information gaps. Unsurprisingly, therefore, the measures the article puts forth to resolve this problem centre on facilitating the flow of information and on redistributing the burden of legal costs within the state and in the wider society.

\subsubsection{Economic factors}

Other factors include the labour-intensive nature of much legal work due to the growing complexity of the law, the risk of adverse costs orders in litigation, a gradual move away from the more standard use of scales of costs, the comparatively insular nature of the legal profession (in Australia, for example), and the costs that accumulate as a result of work duplicated by attorneys and advocates. ${ }^{65}$

\subsubsection{Other factors}

A range of factors has been traditionally attributed to the intractable nature and associated expense of the legal environment. These include the inherent unpredictability of the litigation process and the common law system as a whole, the adversarial system that encourages a "warrior mentality", lawyers' attitudes towards the prosecution of cases before courts, ${ }^{66}$ and the culture around legal practice that presents exclusive offices and expensive fees as corresponding to expertise and ability. ${ }^{67}$

These factors raise the question whether society should enlist lawyers at all when its members lock horns. Insofar as they flag lawyers' attitudes rather than the scarcity of resources, these factors challenge the wisdom of this article's market-led strategy for getting to grips with non-market circumstances.

\subsection{Consequences}

As a consequence of the unaffordability of legal services, the majority of poor Namibians and those with moderate income do not receive the amount and type of legal services they need. Even more specifically, women do not

\footnotetext{
65 See Centre for Innovative Justice Affordable Justice 11.

66 Usman et al 2016 Beijing L Rev 83, 86. This study, conducted in Nigeria, revealed that lawyers' attitude towards the prosecution of cases before courts is the main reason for delaying cases in Nigerian courts.

67 Centre for Innovative Justice Affordable Justice 11.
} 
get the legal services they need when husbands, domestic partners, fathers, brothers, boyfriends, or friends victimise them.

As a further consequence of costly legal services, many litigants appear before court without legal representation. This plight betrays the spirit and the letter of the Namibian Constitution, which upholds the principle of access to justice for all.

\subsection{The fundamental dilemma}

The goal of decreasing the price, if not the cost, of legal services carries with it the danger that, beyond a certain threshold, the lowering of prices will create a disincentive for currently practising lawyers, law students, and those contemplating law as a possible major at university. The Constitution obliges the state to broaden access to justice, which entails making justice affordable, but this noble ideal may end up scaring the most gifted Namibians away from legal studies and the legal profession. If that happens, everybody will lose out, including those well-intentioned activists pushing for more accessible justice. Social and economic development requires that universities supply the market with enough exceptionally talented law graduates.

On the other hand, decreasing the costs of legal services may grossly distort the relative scarcity of those services. For that reason, the high cost of legal services is first and foremost an economic problem. Ultimately, the prices of legal services will have to reflect their scarcity, though there is, to date, no fool-proof and universally accepted formula for determining how lawyers or their clients should value these services. To make matters worse, the scarcity of legal services will most likely "persist", indicating that costs will keep on ballooning. ${ }^{68}$ The basic dilemma is to decrease costs while preserving the financial profitability of the profession.

\subsection{Are legal costs high or heightened?}

At current levels and from an economic perspective, lawyers overcharge their clients, as the present structure of the legal market does not justify their hefty fees. Here, a distinction must be drawn between the "cost" and the "price" of legal services. While people often use these two terms interchangeably, they do not refer to the same thing. ${ }^{69}$ The "cost" of legal services relates to the resources it takes to produce one unit of legal service

$68 \quad$ See Cohen 2013 JLA 221, 222.

69 See Sowell Economic Facts and Fallacies 119. 
whereas the "price" is the amount of money actually charged as compensation for rendering that unit of service.

The distinction between cost and price assists in understanding why decreasing the prices of legal services may undervalue their real cost, which must necessarily be borne by someone eventually.

It follows from the foregoing that lawyers most probably overcharge their clients. In addition, price levels outstrip the demand for legal services. They also indicate that the supply of lawyers does not match the demand for legal services and that, consequently, the legal market as a whole is not profitable for the majority of admitted legal practitioners. Thus, in all likelihood, increased competition will lower legal fees in Namibia, although it may well discourage people from choosing law as a career if their income from lawyering does not recoup the money they invested in their legal education.

With 700 admitted legal practitioners, the average litigation cost of a represented party at $\mathrm{N} \$ 100,000$, and the average Namibian earning about $\mathrm{N} \$ 95,220$ annually, ${ }^{70}$ it appears that legal fees, at least with respect to litigation, far exceed what most Namibians can afford.

\section{Solutions to the high costs of legal services}

Perhaps the most important and comforting point in this whole debate is realising that innovation still is - and often is - possible. This is just as important given that reports elsewhere suggests that, when it comes to innovation, the legal profession lags behind other professions. ${ }^{71}$

Traditional solutions, while essential to meeting the need for legal services, do not suffice. Legal-assistance funding, pro bono services and legislative reforms are inadequate in lowering the cost of legal services, including legal representation, which remains too expensive for most Namibians to afford. However, strengthening insurance could drive costs down remarkably.

\subsection{Traditional solutions}

\subsubsection{Insurance}

Traditionally the law seeks to lessen the costs of legal services for consumers through insurance. Insurance is a solution used in other

$707,935 \times 12=95,220$. See NSA Namibia Labour Force Survey 2018 67-68 (reporting that the average wage in Namibia is $N \$ 7,935$ per month).

Centre for Innovative Justice Affordable Justice 12. 
professions, especially in medicine. Just as insurance can cover patients who could not otherwise cover the costs of medical care, legal insurance enables people who would otherwise lack the money to pay for the costs of legal services to afford such services.

Namibia does not have many legal insurance schemes. Private firms offer the existing schemes; the government has not engaged in the legalinsurance business.

Legal Shield, owned by TrustCo, is the largest provider of legal insurance. LegalWise is another key yet smaller player. In return for their monthly premiums, these insurance schemes allow people to secure legal services when they need them.

Unfortunately, the number of people covered by these two main legal insurance schemes are dwarfed by the number of people who do not have such schemes and by the sheer need for legal services in the country.

\subsubsection{Legal aid (publicly funded)}

Legal aid can be provided by government, by civil society, or in some instances by the law faculties of universities. In Namibia the Ministry of Justice has a Directorate of Legal Aid. Situated strategically in front of the busy Magistrate's Court in Katutura, Windhoek, the Directorate provides legal aid to indigent people.

The Supreme Court handed down a general test in Mwilima for how the state should extend legal aid. ${ }^{72}$ Before Mwilima, the criteria for granting legal aid were inconsistent. The Constitution provided for legal aid, subject to the economic resources of the state: ${ }^{73}$

The State shall actively promote and maintain the welfare of the people by adopting, inter alia, policies aimed at ... a legal system seeking to promote justice on the basis of equal opportunity by providing free legal aid in defined cases with due regard to the resources of the State.

Two factors have watered down this constitutional provision. First, the Constitution makes legal aid subject to the (limited) economic resources of the state. Second, it places this provision in Chapter 11, which does not bind the state although it may guide the government and the courts in interpreting

\footnotetext{
72 Government of the Republic of Namibia v Mwilima 2002 NR 235 (SC).

73 Article 95(h) of the Constitution.
} 
laws based on that provision. ${ }^{74}$ This means that the courts cannot enforce this constitutional provision on legal aid directly.

The constitutional provision clashed with the provisions of the Legal Aid Act 29 of 1990. The Act empowered the Director of Legal Aid to grant legal aid in deserving cases when the legal aid applicant is poor and when it safeguards the interest of justice to grant such aid, ${ }^{75}$ but subject to the available economic resources of the state. ${ }^{76}$

The provisions of the Legal Aid Act contradicted the ICCPR. The ICCPR forms part of Namibian law by virtue of Article 144 of the Constitution, following Namibia's ratification of that international treaty. ${ }^{77}$ The standard for granting legal aid in terms of the ICCPR is the interests of justice. ${ }^{78}$ In Mwilima the Supreme Court preferred the standard in the Covenant and held that the Namibian state should provide legal assistance when the interests of justice so require. ${ }^{79}$ The ICCPR differs from the Legal Aid Act in that the ICCPR does not condition legal assistance on the availability of resources, but on the interests of justice. ${ }^{80}$

Whereas the decision in Mwilima appears progressive, it has not solved the inadequacy of legal aid in increasing access to justice. To begin with, the budget of the Directorate remains meagre in view of the comparatively enormous needs for legal representation. To be sure, the Directorate's

74 See art 101 of the Constitution: "The principles of state policy contained in this Chapter shall not of and by themselves be legally enforceable by any Court, but shall nevertheless guide the Government in making and applying laws to give effect to the fundamental objectives of the said principles. The Courts are entitled to have regard to the said principles in interpreting any laws based on them." Section 10(2) of the Legal Aid Act 15 of 1995.

Government of the Republic of Namibia v Mwilima 2002 NR 235 (SC) 251D-H. Chief Justice Strydom held that: "I think there can be little doubt that art 95(h) expresses no more than the intention of [the government] to promote justice by providing statutory legal aid to those who have not the means to afford legal representation. However, given Namibia's resources in manpower and finances it would be, and still is, impossible to provide free legal aid for each and every person who is indigent and in need of such assistance. This fact is recognised in that the State limited itself to certain defined cases and in regard to available resources." Emphasis added. Government of the Republic of Namibia v Mwilima 2002 NR 235 (SC) 259D-260B. Article 14(3)(d) of the ICCPR: "In the determination of any criminal charge against him, everyone shall be entitled to the following minimum guarantees in full equality: to be tried in his presence, and to defend himself in person or through legal assistance of his own choosing; to be informed, if he does not have legal assistance, of his right; and to have legal assistance assigned to him in cases where the interests of justice so require, and without payment by him in any such case if he does not have sufficient means to pay for it." Emphasis added. Government of the Republic of Namibia v Mwilima 2002 NR 235 (SC) 260D-F. 
budget for the 2008-2009 financial year reportedly amounted to a mere $\mathrm{N} \$ 17.8$ million, of which it earmarked only 10 million to pay the fees of the lawyers representing poor citizens on the Directorate's behalf. ${ }^{81}$ Besides, budget cuts ${ }^{82}$ and financial crises decrease legal-aid budgets, as do the recession and the COVID-19 pandemic the Namibian government is now weathering.

To make matters worse, the Act hardly says anything about how to allocate legal aid. Unlike the medical field, the legal profession does not have judicious rules on how to allocate or ration scarce resources. ${ }^{83}$

\subsubsection{Private legal assistance}

\subsubsection{Non-governmental organisations}

Non-governmental organisations (NGOs) can provide legal aid. In Namibia the Legal Assistance Centre (LAC), a human rights NGO created in 1988, represents clients in constitutional-law and public-interest matters. It receives donations and thus relies on the public's generosity.

However, just like the aid provided by the government, the assistance given by the LAC pales in comparison to the tremendous need for legal services. Plus, its reliance on donations implies that the Centre does not always have the financial resources to represent indigent people.

\subsubsection{Legal aid clinics}

Legal services can be provided through clinical legal education. In legal aid clinics, law students represent clients or assist their supervisors to represent them, typically in a law office within the law school itself. ${ }^{84}$

At the University of Namibia (UNAM), the Legal Aid Clinic in the Faculty of Law assists the poor with their legal problems. The Clinic is headed by a Coordinator, a legal practitioner who also acts as a lecturer in the Faculty of Law. Final-year students in the four-year LLB programme of the Faculty work under the Coordinator as part of their practical legal training. In the light of the relative success of legal aid clinics such as the Law Clinic at Stellenbosch University, UNAM's Legal Aid Clinic holds tremendous

81 Menges 2008 https://www.namibian.com.na/48477/archive-read/Legal-Aid-battlingcash-flow-problems.

82 Damaseb 2019 NLJ 29

83 See Cohen 2013 JLA 221, 222-223.

84 See Joy 2012 Boston College Journal of Law \& Social Justice 309-330. 
potential in advocating the reform of existing laws, apart from providing legal services to poor clients. The UNAM Legal Aid Clinic could also add gender issues to its list of priorities.

Here again, however, the provision of legal assistance by the Clinic, although very useful, does not meet the demand for legal services. For one thing, legal aid clinics generally cost more than normal classroom courses as they require more faculty resources ${ }^{85}$ In particular, at UNAM the Legal Aid Clinic calls for the supervision of students by more than two admitted legal practitioners ideally, who should also be members of the Faculty. Not only does this requirement demand more resources than those of normal classroom courses, but - in 2018 - only four (out of about 16) faculty members were licensed to practice law in Namibia, ${ }^{86}$ three of whom directly coordinated and supervised the Clinic.

Moreover, the Legal Aid Clinic is restricted in terms of the area of law in which it can provide assistance and also in terms of capacity. Most cases dealt with by the Clinic in 2017 related to divorce and separation. While these cases greatly affect women, the Clinic should ideally also address itself to other issues that impact on women's lives, such as domestic violence.

But since the Clinic does not have a public mandate to advise clients, the number of clients it can advise in a given year varies and entirely depends on the Clinic's capacity. The Clinic can turn away even people who pass the means test if it lacks capacity at that point in time. Incidentally, students work in the Clinic only for two hours a week, which slows down the process of advising and assisting clients.

\subsubsection{Pro bono legal services}

Some law firms engage in pro bono lawyering. Pro bono refers to the provision of legal services free of charge. In Namibia, some law firms engage in pro bono work. On the other hand, no statistics exist in the public domain on the amount of pro bono work that lawyers carry out annually and the number of female clients or the gender-sensitive disputes they advise on and handle. Sadly, the current situation suggests that pro bono work has not significantly dented the justice-accessibility problem in Namibia.

85 Joy 2012 Boston College Journal of Law \& Social Justice 309-310.

86 UNAM Faculty of Law Prospectus 2018 1-3. 
Several firms hire law graduates as candidate legal practitioners, some of whom carry out pro bono work. Firms may pay their candidate practitioners (the rules of the LSN do not oblige them to do so); but some firms train them without paying them, which could contribute to lowering legal fees.

\subsubsection{Paralegals}

The Faculty of Law at UNAM offers a diploma in paralegal studies. The diploma equips students with the tools needed to work as paralegals. A law firm may thus reduce the price it charges to clients by giving to paralegals some technical work that would previously have been done by legal practitioners. $^{87}$

Nonetheless, no evidence exists of the impact of paralegals on the costs of legal services or women's access to those services. And, given the present situation of prohibitive costs, one can assume that the assistance of paralegals is nowhere near dramatically lowering those costs.

\subsubsection{Judges-led case management system}

In inquisitorial legal systems, judges lead trials. Those systems have the major advantage of disposing of cases more quickly than in lawyercontrolled systems such as the adversarial trial procedure in common-law jurisdictions. This case management system defines civil-law systems.

Despite being a common-law jurisdiction with an adversarial trial procedure, Namibia has taken a few leaves from the civil-law judge's book and embraced a case-management system led by judges. ${ }^{88}$ The "overriding objective" of the new High Court rules is to "facilitate the resolution of the real issue in dispute justly, efficiently and cost effectively as far as practicable". 89 This new "civil justice architecture", according to the High Court Judge President, has allowed that Court to process cases more quickly, thereby reducing legal costs. ${ }^{90}$

\subsubsection{Alternative dispute resolution}

Not all cases need to go to court or resort to formal dispute-resolution mechanisms. This holds true especially in traditional African societies,

See Tamanaha 2013 J Leg Ed 173, 174.

See Damaseb Promoting Access to Justice in the High Court.

Rule 1(2)-(3) of the Rules of the High Court of Namibia (GN 4 in GG 5392 of 17 January 2014). See also Damaseb 2019 NLJ 30. Emphasis added.

90 Damaseb 2019 NLJ 45-46. 
which conceived justice as reconciling people and restoring harmony in society, rather than pitting community members against one another through adjudication and litigation.

Recourse to alternative dispute resolution (ADR) mechanisms can go a long way towards decreasing the costs of legal services. In Namibia the chief registrar of the High Court, Elsie Schickerling, said at a briefing in 2015 that she has calculated that successful mediation has already saved litigants in High Court matters tens of millions of dollars in legal fees. ${ }^{91}$

High Court Judge President, Petrus Damaseb, estimated that, in 2015 and 2016, litigants saved at least $N \$ 102$ million thanks to court-connected mediation. ${ }^{92} \mathrm{He}$ believes that this ADR form and the new civil justice system yield these fruits partly because the state pays the mediators so that the parties do not have the shoulder the burden of the mediation. ${ }^{93}$

Damaseb correctly stresses that remunerating mediators gives the parties an incentive to settle their differences out of court. In the 2015-2016 period, the state disbursed to the mediators an amount of $\mathrm{N} \$ 4,4$ million. Nevertheless, the parties still have to spend huge sums before they can reach the stage where they can decide whether to litigate or settle outside. Moreover, court-connected mediation will not avail parties whose matters do not call for any lawsuit. In the end, the efficiency of the court-connected mediation hinges on whether the state expends more in sustaining civil litigation than in paying mediators to take lawsuits out of the system.

The Faculty of Law at UNAM also offers a diploma in arbitration. This noble initiative holds the potential of lowering costs. However, arbitration - in and of itself - cannot solve the unaffordability of legal services, if only because the demand for legal services does not relate to dispute resolution only, but also involves such non-litigation services as drafting contracts, representing clients on company boards, and so on.

\subsubsection{Public prosecutions}

Though people do not usually think of public prosecutions as a cost-saver, they actually have that effect. In criminal matters, only the accused faces

\footnotetext{
91 Menges 2015 https://www.namibian.com.na/134524/archive-read/Mediationsaving-money-and-court-time.

$92 \quad$ Damaseb 2019 NLJ 46.

93 Damaseb 2019 NLJ 46.
} 
the high probability of having to represent himself in court. ${ }^{94}$ The prosecutor (the state) stands in for the complainant such that the complainant does not have to bear any costs regarding his or her case.

Nevertheless, given that not all matters for which clients need assistance are criminal cases (in fact, most disputes qualify as civil matters), public prosecutions will not solve or revolutionise the affordability of litigation services.

Slimming down prosecutions could cut the cost of litigation. High Court Judge President Damaseb recommended that Namibia codify pleabargaining. ${ }^{95} \mathrm{He}$ noted that plea bargains helped Malaysia reduce criminal trials $^{96}$ without explicitly mentioning whether they slashed litigation costs. Ndeunyema clearly suggested that plea bargains can bring down those costs in Namibia. ${ }^{97}$ Granted, plea bargaining will cut costs in criminal cases, but it will not lower expenses and barriers to justice in civil matters.

\subsection{Solutions used in jurisdictions other than Namibia}

The problem with traditional solutions to tackle the cost of legal services is that they do not reach a great number of people. Traditional solutions have narrow scopes; hence the need for systemic, structural, broad-based solutions.

\subsubsection{Small claims courts}

Small claims courts increase access to justice in cases involving minor issues. Certain parts of the globe, such as North America, already use these courts.

The Law Reform and Development Commission of Namibia (LRDC) has mooted and seriously studied the idea of small claims courts. In fact, the LRDC included in its report a draft bill on small claims court. Parliament never adopted this bill. This is regrettable as small claims courts would have most probably decreased the costs of legal services and thereby increased

$94 \quad$ Tjatjara 2019 https://www.namibian.com.na/184821/archive-read/Justice-MustHave-Legs-\%E2\%80\%A6-And-Guts. The author, a former prosecutor and former magistrate in Namibia, laments that the vast majority of accused in Namibia do not have legal representation in court.

95 Damaseb Promoting Access to Justice in the High Court 75.

96 Damaseb Promoting Access to Justice in the High Court 56.

97 Ndeunyema 2012 NLJ 63, 69. 
access to justice by drastically decreasing the need for legal representation, for instance.

Fortunately, the new Justice Minister, Yvonne Dausab, has declared that she intends to set up small claims courts. Dausab, the former LRDC Chairperson, may have figured out that those courts will not only broaden access to justice but will, above all, bring justice much closer to women and other vulnerable groups, such as the poor, the elderly, and people living with a disability.

Nonetheless, parliament has not yet established any small claims courts. And a great many small claims are not mediated by community courts and magistrates' courts, which means that people resolve many small claims outside of courts by other means such as private self-help, including threats and physical violence.

Despite their real effect on costs and access to justice, small claims courts alone would not substantially decrease the costs of legal services for at least two reasons. First, the need for legal services goes beyond litigation. Second, small claims courts deal only with small claims made in civil law matters. They do not deal with criminal cases.

\subsubsection{Contingent fee arrangements}

Conditional or contingent fee arrangements (CFAs) could decrease the costs of legal services. Plus, they constitute an alternative to the hourly billing model. ${ }^{98} \mathrm{~A}$ client pays a "contingency fee" when a lawyer agrees to take no fee directly from his client but indirectly as a certain percentage share of the judgment his client will receive if the client's case succeeds. ${ }^{99}$

The US pioneered such arrangements, ${ }^{100}$ and Namibia does not legally permit them.

CFAs have been greeted with a barrage of scathing criticisms in several countries. Among others, they have been blamed for giving windfalls to lawyers and encouraging lawsuits because of the possibility of such windfalls, for inciting litigation (at the expense of ADR methods), and for fostering litigious societies. ${ }^{101}$

\footnotetext{
$98 \quad$ Lansing et al $2009 \mathrm{~J}$ Legal Prof 301.

$99 \quad$ Lansing et al $2009 \mathrm{~J}$ Legal Prof 301; Melamed 2006 Cardozo L Rev 2433.

100 Melamed 2006 Cardozo L Rev 2433.

101 See Melamed 2006 Cardozo L Rev 2433, 2434, 2436.
} 
In addition, CFAs have quite a limited impact on costs. First, they induce lawyers to reject criminal cases because those cases do not involve money, even when courts acquit their clients. Second, experience in the US suggests that lawyers turn away the majority of clients who contact them to work on a contingency fee basis; and not so much because those cases cannot reward lawyers financially, but because those lawyers may believe that the persons those clients wish to sue lack liability. ${ }^{102}$

\subsubsection{Representative class proceedings}

These proceedings may decrease the price of litigation since even poor clients can pool their money so as to afford a collective action against a defendant. Often known as "class action", these proceedings are not available in the Namibian legal system, with the notable exception of labour law.

In Namibia, parties can avail class actions in the specific area of labour arbitration. These class actions are laid down in Rule 17 of the Rules Relating to the Conduct of Conciliation and Arbitration Before the Labour Commissioner. ${ }^{103}$ Rule $17(1)$ reads as follows:

One or more members of a class of employers or employees may refer a dispute to arbitration on behalf of all members of such a class, and must [...] file with the Labour Commissioner and serve the respondent with an application for class certification .... .

The Lysteriosis class action case in South Africa provides a good example of how these proceedings could lower legal costs. Unfortunately, despite the great potential it holds in terms of cost savings, class actions do not exist outside the narrow field of labour dispute arbitration in Namibia.

\subsubsection{Alternative business structures}

Made in the United Kingdom (UK), alternative business structures (ABSs) allow legal practitioners to partner with non-legal outsiders to offer both legal and non-legal services to the public. The public is in turn allowed to invest in ABSs. ${ }^{104}$

\footnotetext{
102 Lee 2015 U Miami L Rev 499, 503-504.

103 Rules Relating to the Conduct of Conciliation and Arbitration Before the Labour Commissioner: Labour Act, 2007. Also see the following cases by the Namibian Labour Court: Stantoll Properties CC v Shiimi 2015 NAHCMD 15 (22 July 2015); Springbok Patrols (Pty) Ltd v Jacobs 2013 NALCMD 17 (2013).

104 Hill 2017 Or Rev Int'l L 135, 136.
} 
ABSs depart from the traditional law firm. They manifest the "tumultuous change" that the delivery of legal services is undergoing across the globe. ${ }^{105}$ They may decrease the cost of legal services, although doubts persist as to whether such structures will have the desired effect in Namibia or any other jurisdiction.

\subsubsection{Offshoring}

In developed countries, firms have engaged in subcontracting legal work overseas. Legal offshoring has grown considerably since the 2008 global financial crisis, and it is a "tempting cost-saver". ${ }^{106}$ Buoyed by technology, law firms in developed nations have begun to outsource a wider range of their legal offerings, including labour-intensive back-office tasks, from document indexing to rudimentary legal research and transcription. ${ }^{107}$

Although it saves costs and improves operations, this practice raises serious confidentiality issues as law firms have to send work overseas, creating the risk that this process breaches attorney-client privilege. ${ }^{108}$ Most importantly, this practice will not serve Namibia since, as a developing country, it is a low-cost legal system, compared with those of developed and industrialised nations such as the US, the UK, Canada, and Australia.

\subsubsection{Taxes}

What about taxes? The government could create taxes or increase existing ones to provide for legal assistance. Or it could levy taxes to finance nofault compensation schemes like those that some countries apply to, say, traffic accidents, defective products, and medical malpractice.

The law could empower the LSN to levy a certain tax to fund the provision of free legal aid to the most vulnerable sections of society. This strategy could prove effective in expanding legal-aid budgets and in extending them to the protection and promotion of women's rights. Policy makers could focus on this sort of initiative as tax law constitutes the branch of a country's legal system best suited to (re)distribute wealth and resources. ${ }^{109}$ This could give plenty of food for thought, but it is a debate for another day.

\footnotetext{
105 Hill 2017 Or Rev Int'l L 135.

106 Schultz $2010 \mathrm{~J}$ Corp L 639.

107 Susskind and Susskind Future of the Professions 68; Wollins 2007 ABA Business Law Today 61.

108 Schultz $2010 \mathrm{~J}$ Corp L 639, 661.

109 See Shaviro "Economics of Tax Law" $106 \mathrm{ff}$.
} 


\subsection{New approaches and growing trends}

\subsubsection{Expansion of the regulatory state}

Schleifer, a Harvard economist, points to the rise of the regulatory state and the decline of courts. He first observes that regulation pervades society because, compared with litigation, it more efficiently solves delictual and contractual disputes cheaply, predictably, and impartially. ${ }^{110} \mathrm{He}$ chiefly argues that, when courts are expensive and unpredictable, people look for alternatives and that around the world this search for better disputeresolution mechanisms has taken the form of regulation. ${ }^{111}$

More regulators could lower prices for various legal services. Regulators and other state-owned enterprises (SOEs) can indeed provide services at below-market prices. In fact, the raison d'être of many SOEs is precisely to provide services that the private sector does not find profitable or to render essential services at affordable or otherwise reduced prices. In these cases, SOEs not so much decrease the costs of legal services as they cover a large portion of those costs so that citizens do not actually pay the full value of those services.

\subsubsection{Deployment of information technology}

Susskind and other experts have observed that information and communications technologies (ICTs) have exerted downward pressures on prices in many economic sectors and professions. ${ }^{112}$ The staggering amount of free software on the Internet, such as Google Vault, has made life cheaper not only for clients but for lawyers as well. ${ }^{113}$ Although ICTs are disruptive, they have nonetheless the effect of decreasing the costs and prices in those sectors and professions.

In particular, Namibian policy makers could explore the idea of developing a mobile application. This application could compare prices of legal services offered by the different legal practitioners in Namibia. However, for such an application to work effectively, there must be a strong incentive or a legal obligation for legal practitioners to post their prices or forward that information to the LSN.

\footnotetext{
110 Shleifer Failure of Judges.

111 Shleifer Failure of Judges.

112 See Susskind and Susskind Future of the Professions; Susskind End of Lawyers?

113 Krause 2007 ABA Journal 57.
} 
One source of price dispersion (i.e. differences between prices quoted at any given time) $)^{114}$ is the costs to sellers of ascertaining their rivals' asking prices. By posting the different prices charged by different providers of legal services, this Internet application reduces price dispersion and infuses the legal profession with stiffer competition. ${ }^{115}$ This may, however, prompt some law firms to form cartels and agree to fix prices. ${ }^{116}$ This application would nonetheless add value and increase the efficiency of the market for legal services by lubricating the flow of information in that market.

\subsubsection{Legal services by non-lawyers}

Another possible avenue for the lowering of legal costs is the provision of selected legal services by non-lawyers. To achieve that goal, lawmakers must reduce or eliminate lawyers' exclusive rights to render legal services. ${ }^{117}$ Lawmakers can allow paralegals and other professionals with less training than admitted legal practitioners to practice in certain areas of law. ${ }^{118}$

If legal services are broken down into their most individual tasks, it becomes evident that not all of these individual tasks requires that legal practitioners intervene. For example, if certain contracts can be written only by lawyers, paralegals and other non-lawyers can use templates or sell them to clients.

Similarly, a host of companies now offer legal services though they are not law firms. In Namibia some banks write wills for their clients, while some tax firms advise their clients on tax matters by coupling these pieces of advice with some information pertaining to the applicable rules of tax law.

\subsubsection{Growth of in-house lawyers}

In-house lawyers allow companies to keep their legal costs down. And the growth of in-house corporate legal departments has decreased companies' reliance on private lawyers, which has diminished companies' legal costs. ${ }^{119}$

\footnotetext{
114 Hopkins "Price Dispersion" 10692 (defining "price dispersion" as a situation where "different sellers offer different prices for the same good in a given market").

115 Stigler $1961 \mathrm{~J}$ Polit Econ 213, 219.

116 OECD 2010 http://www.oecd.org/competition/cartels/48379006.pdf.

117 Woolley and Farrow 2016 Texas A\&M L Rev 549, 550.

118 Woolley and Farrow 2016 Texas A\&M L Rev 549, 550.

119 Dzienkowski 2014 Fordham L Rev 2995, 2996.
} 
However, in-house lawyers cannot handle all legal matters in a business. Complex matters often require that a company which employs in-house lawyers nonetheless hires the services of outside lawyers.

\subsubsection{Subsidies}

The government could subsidise legal assistance to the citizenry. ${ }^{120} \mathrm{~A}$ subsidy is a financial contribution made by the government or another public body that confers a benefit on an enterprise, a group of enterprises or an industry. ${ }^{121}$

Subsidisation, though a theoretical possibility, seems unlikely to turn things around in the Namibian legal profession. If the government already struggles to give legal aid to the neediest, subsidies will not make any difference. Actually, on closer scrutiny, the legal aid provided by the government already functions as a subsidy. Subsidising legal assistance would in fact amount to increasing the funds allocated to the Directorate of Legal Aid.

In the current and foreseeable future economic and budgetary conditions, the government will lack the means to subsidise the provision of legal assistance to such an extent that it secures near-universal access to justice.

\section{Competition and (de)regulation: The keys to the cost of legal services}

The survey of the existing literature and the possible solutions to the affordability conundrum just conducted and identified in the immediately preceding section have unearthed central questions of competition and the overall regulation of the legal profession. One sentence can sum up the effect of competition: greater competition leads to lower prices, higher quality, greater availability of better and more varied professional services. ${ }^{122}$ Both the European Commission (EC) and the Organisation for Economic Co-operation and Development (OECD) have adopted this view. In addition, as competition mounts, lawyers and law firms will continue to innovate to survive in the new marketplace. ${ }^{123}$

\footnotetext{
$120 \quad$ See Centre for Innovative Justice Affordable Justice 4.

121 Also see art 1 of the World Trade Organization Agreement on Subsidies and Countervailing Measures (1994).

122 See Chaserant and Harnay 2013 Eur J Comp Econ 268.

123 See Hill 2017 or Rev Int'l L 135, 137.
} 
With reference to the regulation of legal services, scholars divide into different schools of thought. They approach the regulation of legal services in at least three ways, namely the public interest approach, the private interest approach, and the asymmetrical information approach. According to the public interest perspective, market failures justify the regulation of the market for legal services. The private interest approach takes for granted that private interests may capture that market. Chaserant and Harnay, who subscribe to the asymmetrical information approach, point out that the public interest and the private interest perspectives have failed because they focus only on debates between regulation and deregulation. ${ }^{124}$ They claim that those perspectives thus pay little attention to information asymmetries between regulators and the regulated entities, which implies that those perspectives fail (1) to analyse how those asymmetries impact on the efficiency of regulation and (2) to account for the specificity of legal services. ${ }^{125}$

Stephen does not concern himself with the details of regulating the various legal professions and legal service markets. Rather, he questions the need for a specific regulatory regime for legal service markets distinct from general competition law. ${ }^{126}$ In similar vein, an instructive report by Copenhagen Economics (CE report) recognises that liberalising the legal profession and increasing competition in it can benefit consumers. ${ }^{127}$ It insists that particular circumstances in the Danish legal market restrict the benefit of liberalisation in Denmark. That report is relevant to other countries, including Namibia, even if it mainly targeted a Danish audience.

According to Marks, some serious information asymmetries make competition unlikely to produce efficient outcomes. ${ }^{128}$ Most clients do not know many lawyers who offer the services they need, neither do they know how to judge their abilities. Likewise, most lawyers do not know the strength of their clients' cases.

\subsection{Regulation of legal services}

The desirable level of regulation or deregulation of legal services depends on their heterogeneity. ${ }^{129}$ The fact that legal services markedly differ

\footnotetext{
124 Chaserant and Harnay 2013 Eur J Comp Econ 268.

125 Chaserant and Harnay 2013 Eur J Comp Econ 268-269.

126 Stephen Date Unknown http://archive.scottish.parliament.uk/business/committees/ historic/justice1/inquiries-02/j1-lps-pdfs/lps-099.pdf.

Olesen and Nielsen Legal Profession 4.

Marks "Rising Legal Costs" 227-235.

Chaserant and Harnay 2013 Eur J Comp Econ 267.
} 
suggests that different services call for different prices. This is an obvious point, but it certainly complicates the regulation and the valuation of those services.

The LSN should eliminate unnecessary regulations. It may review existing regulations and single out those that it should scrap. Performing this exercise would go a long way towards making sure that the LSN get rid of unnecessary or redundant regulations.

\subsection{A legal consumer advocate}

The Centre for Innovative Justice in Australia recommended the establishment of a Legal Consumer Advocate. ${ }^{130}$ The Legal Consumer Advocate (LCA) would see to it that the legal profession remains competitive by checking that lawyers do not overcharge their clients.

While this sounds like an idea worth exploring, in the Namibian context it would not necessarily require that the state create yet another institution. The LSN may simply assume the functions of the LCA. But for the LSN to perform those functions effectively, it must absolutely quit its role as a representative association of the legal profession and concentrate its activities on regulating the profession. Its lobbying activities as representative of the profession may torpedo efforts to lower prices through greater competition.

\section{Insurance holds the most promising potential}

If structured as a compulsory salary deduction, legal insurance promises the greatest positive impact on costs. By requiring employers to deduct legal insurance monthly from the salaries of their employees, policy makers could protect employees and their dependents in a fashion reminiscent of health insurance. Plus, such an initiative would not necessitate that employers increase salaries, although it would translate into larger deductions from salaries, thus lowering disposable incomes.

The key to this insurance structure, apart from the mandatory-deduction component, lies in the inclusion of an employee's dependents. If it covered an employee's dependents, such a mandatory insurance programme could work, to dramatic effect. The average household size in Namibia is $3.9,{ }^{131}$ and with a total employed population of 725,742 (about $31 \%$ of the

\footnotetext{
$130 \quad$ Centre for Innovative Justice Affordable Justice 4.

131 NSA Namibia Inter-censal Demographic Survey 201689.
} 
population) ${ }^{132}, 133$ the programme could extend basic legal insurance to 2,8 million people, ${ }^{134}$ more than the entire population. This figure does not faithfully depict external reality, but it nonetheless captures a statistical possibility. For this reason, insurance holds the most promising potential of all the affordability solutions surveyed in this article.

\section{Conclusion}

The affordability conundrum in Namibia features inadequate competition and an overstretched public-assistance government. The ideal solution would thus combine increased competition and broader cost-sharing. Currently, people are "sandwiched" between public assistance and a limited capacity to meet the costs of the private legal market. ${ }^{135}$

Competition boils down to creating an efficient market. In that market, "prices fully reflect all available information". ${ }^{136}$ However, as demonstrated in this article, consumers cannot obtain information about how much legal services cost without hard efforts. This in turn discourages people from even seeking out that information. ${ }^{137}$ One way around this hurdle is to adopt a software application that can compare prices so that consumers know which firm offers the best prices and the best value for money. For such an application to operate effectively, government or the LSN must oblige firms and legal practitioners to advertise their prices.

The most pragmatic option would not so much reduce the prices of legal services as it would modify public assistance and spread more widely the heavy burden of providing public legal assistance. Hence, insurance stands out as the best option, as the most apt at shouldering and sharing the huge responsibility of maintaining a wholesale system of public legal assistance. Plus, it does not threaten the overall profitability of the legal profession. If framed as a mandatory monthly deduction and as covering an employee's dependents, insurance beats all the other law-reform proposals roughed out in this article to resolve the high costs of legal services. The big question this article now leaves open for further inquiry is whether employees would

\footnotetext{
132 NSA Namibia Inter-censal Demographic Survey 201645 (stating that the population size of Namibia was 2324 388).

NSA Namibia Labour Force Survey 201855.

134 The number of people employed in Namibia (i.e. 725,742) multiplied by the average household size (i.e. 3.9) equals 2,639,851.

Centre for Innovative Justice Affordable Justice 4.

Lo "Efficient Markets Hypothesis" 3545.

Also see Stigler $1961 \mathrm{~J}$ Polit Econ 213-219 (stating that empirical research suggests that people tend to engage in less search when the search costs are higher).
} 
accept lower disposable incomes in return for basic legal-insurance coverage.

\section{Bibliography}

\section{Literature}

ABA Report on the Future of Legal Services

American Bar Association Report on the Future of Legal Services in the United States (American Bar Association Washington DC 2016)

Bank of Namibia Challenges of Monetary Policy

Bank of Namibia Challenges of Monetary Policy for Namibia within the Common Monetary Area (CMA) Agreement (Bank of Namibia Windhoek 2000)

Boote and Beile 2005 Educ Res

Boote DN and Beile P "Scholars before Researchers: On the Centrality of the Dissertation Literature Review in Research Preparation" 2005 Educ Res 3-15

Centre for Innovative Justice Affordable Justice

Centre for Innovative Justice Affordable Justice: A Pragmatic Path to Greater Flexibility and Access in the Private Legal Services Market (Centre for Innovative Justice Melbourne 2013)

Chaserant and Harnay 2013 Eur J Comp Econ

Chaserant $C$ and Harnay S "The Regulation of Quality in the Market for Legal Services: Taking the Heterogeneity of Legal Services Seriously" 2013 Eur J Comp Econ 267-291

Cohen 2013 JLA

Cohen IG "Rationing Legal Services" 2013 JLA 221-307

Damaseb Promoting Access to Justice in the High Court

Damaseb PT Promoting Access to Justice in the High Court of Namibia: First Report: The Case for Judicial Case Management (High Court of the Republic of Namibia Windhoek 2010)

Damaseb 2019 NLJ

Damaseb PT "Court-connected Mediation in the High Court of Namibia" 2019 NLJ 29-46 
Dzienkowski 2014 Fordham L Rev

Dzienkowski JS "The Future of Big Law: Alternative Legal Service Providers to Corporate Clients" 2014 Fordham L Rev 2995-3040

Hart Concept of Law

Hart HLA The Concept of Law $2^{\text {nd }}$ ed (Oxford University Press Oxford 1994)

High Court of Namibia Annual Report 2015-16

High Court of Namibia Annual Report 2015-16: Celebrating Judiciary-led Reforms towards Court Excellence and Improved Service Delivery (High Court of Namibia Windhoek 2017)

Hill 2017 Or Rev Int'l L

Hill LL "Alternative Business Structure for Lawyers and Law Firms: A View from the Global Legal Services Market" 2017 Or Rev Int'l L 135-184

Hobbs 2012 Denv U L Rev

Hobbs GJ "Judicial Support for Pro Bono Legal Service" 2012 Denv U L Rev 851-858

Holmes 1897 Harv L Rev

Holmes OW "The Path of the Law" 1897 Harv L Rev 457-478

Hopkins "Price Dispersion"

Hopkins E "Price Dispersion" in Palgrave Macmillan The New Palgrave Dictionary of Economics (Palgrave Macmillan London 2018) 10692-10695

Jauch and Tjirera "Need for Developmental State Intervention"

Jauch $\mathrm{H}$ and Tjirera $\mathrm{E}$ "The Need for Developmental State Intervention in Namibia" in Kanyenze G et al (eds) Towards Democratic Developmental States in Southern Africa (Weaver Press Harare 2017) 135-199

Joy 2012 Boston College Journal of Law and Social Justice Joy PA "The Cost of Clinical Legal Education" 2012 Boston College Journal of Law and Social Justice 309-330

Klaaren 2014 The Salon

Klaaren J "The Cost of Justice" 2014 The Salon 21-25

Krause 2007 ABA Journal

Krause $J$ "The Cost of Free: Don't Bet the Firm on No- or Low-price Software" 2007 ABA Journal 57 
Lansing et al $2009 \mathrm{~J}$ Legal Prof

Lansing P et al"The Ethics of Contingent Fees in Legal Service Businesses" 2009 J Legal Prof 301-316

Law and Development Partnership Developing a Portfolio

The Law and Development Partnership Developing a Portfolio of Financially Sustainable, Scalable Basic Legal Service Models: Costing Methodology Paper (The Law and Development Partnership London 2016)

Lee 2015 U Miami L Rev

Lee EG "Law without Lawyers: Access to Civil Justice and the Cost of Legal Services" 2015 U Miami L Rev 499-517

Lo "Efficient Markets Hypothesis"

Lo AW "Efficient Markets Hypothesis" in Palgrave Macmillan The New Palgrave Dictionary of Economics (Palgrave Macmillan London 2018) 35433560

Marks "Rising Legal Costs"

Marks RE "Rising Legal Costs" in Fox R (ed) Justice in the Twenty-first Century (Cavendish London 1999) 227-235

Melamed 2006 Cardozo L Rev

Melamed $\mathrm{P}$ "An Alternative to the Contingent Fee - An Assessment of the Incentive Effects of the English Conditional Fee Arrangement" 2006 Cardozo L Rev 2433-2464

Morris Leadership on the Federal Bench

Morris JB Leadership on the Federal Bench: The Craft and Activism of Jack Weinstein (Oxford University Press Oxford 2011)

Mwinga et al Namibia Fiscal Policy Analysis

Mwinga M et al Namibia Fiscal Policy Analysis - March 2019: Namibia's Fiscal Policy at the Cross Road (First Capital Windhoek 2019)

Ndeunyema 2012 NLJ

Ndeunyema NML "Igniting the Plea Bargaining Discourse in Namibia: What is it and Do we Need it?" 2012 NLJ 55-81

NSA Namibia Inter-censal Demographic Survey 2016

Namibia Statistics Agency Namibia Inter-censal Demographic Survey: 2016 Report (Namibia Statistics Agency Windhoek 2017) 
NSA Namibia Labour Force Survey 2014

Namibia Statistics Agency The Namibia Labour Force Survey: 2014 Report (Namibia Statistics Agency Windhoek 2015)

NSA Namibia Labour Force Survey 2016

Namibia Statistics Agency The Namibia Labour Force Survey: 2016 Report (Namibia Statistics Agency Windhoek 2017)

NSA Namibia Labour Force Survey 2018

Namibia Statistics Agency The Namibia Labour Force Survey: 2018 Report (Namibia Statistics Agency Windhoek 2019)

Office of the Ombudsman 2013 Baseline Study Report on Human Rights Office of the Ombudsman 2013 Baseline Study Report on Human Rights in Namibia (Office of the Ombudsman Windhoek 2013)

Olesen and Nielsen Legal Profession

Olesen HB and Nielsen CK The Legal Profession: Competition and Liberalisation (Copenhagen Economics Copenhagen 2006)

OMB Research Prices of Individual Consumer Legal Services

OMB Research Prices of Individual Consumer Legal Services (Legal Services Board Kent 2016)

Schultz $2010 \mathrm{~J}$ Corp L

Schultz Cl "Legal Offshoring: A Cost-benefit Analysis" 2010 J Corp L 639661

Semega et al Income and Poverty in the United States

Semega JL et al Income and Poverty in the United States: 2016 (US Government Printing Office Washington DC 2017)

Shaviro "Economics of Tax Law"

Shaviro D "The Economics of Tax Law" in Parisi F (ed) Oxford Handbook of Law and Economics Vol 3 (Oxford University Press Oxford 2017) 106-126

Shleifer Failure of Judges

Shleifer A The Failure of Judges and the Rise of Regulators (MIT Press Cambridge, Mass 2012)

Snyder 2019 J Bus Res

Snyder H "Literature Review as a Research Methodology: An Overview and Guidelines" 2019 J Bus Res 333-339 
Sowell Economic Facts and Fallacies

Sowell T Economic Facts and Fallacies $2^{\text {nd }}$ ed (Basic Books New York 2011)

Stigler $1961 \mathrm{~J}$ Polit Econ

Stigler G "The Economics of Information" 1961 J Polit Econ 213-225

Susskind End of Lawyers?

Susskind R The End of Lawyers? Rethinking the Nature of Legal Services (Oxford University Press Oxford 2010)

Susskind and Susskind Future of the Professions

Susskind R and Susskind D The Future of the Professions: How Technology will Transform the Work of Human Experts (Oxford University Press Oxford 2015)

Tamanaha $2013 \mathrm{~J}$ Leg Ed

Tamanaha BZ "Is Law School Worth the Cost?" 2013 J Leg Ed 173-188

UNAM Faculty of Law Prospectus 2018

University of Namibia Faculty of Law Prospectus 2018 (UNAM Faculty of Law Windhoek 2018)

Usman et al 2016 Beijing L Rev

Usman DJ et al "An Inquiry on the Affordability of Legal Services and the Appropriateness of Regular Courts for Consumer Redress in Nigeria" 2016 Beijing L Rev 83-94

Wollins 2007 ABA Business Law Today

Wollins K "Outsourcing Legal Services Overseas" 2007 ABA Business Law Today 61

Woolley and Farrow 2016 Texas A\&M L Rev

Woolley A and Farrow T "Addressing Access to Justice Through New Legal Service Providers: Opportunities and Challenges" 2016 Texas A\&M L Rev 549-579

Zongwe International Law in Namibia

Zongwe DP International Law in Namibia (Langaa Bamenda 2019)

Zongwe "Legal Significance of the Euro Crisis"

Zongwe D "The Legal Significance of the Euro Crisis for the Southern African Monetary Union" in Hugo C and du Toit S (eds) Annual Banking Law 
Update 2020: Recent Legal Developments of Special Interest to Banks (Juta Cape Town 2020) 75-94

\section{Case law}

Government of the Republic of Namibia v Mwilima 2002 NR 235 (SC)

Kauesa v Minister of Home Affairs 1994 NR 102 (HC)

Kauesa v Minister of Home Affairs 1995 NR 175 (SC)

Springbok Patrols (Pty) Ltd v Jacobs 2013 NALCMD 17 (31 May 2013)

Stantoll Properties CC v Shiimi 2015 NAHCMD 15 (22 July 2015)

State $v$ Kau 1995 NR 1 (SC)

\section{Legislation}

Constitution of Namibia, 1990

Legal Practitioners Act 15 of 1995

\section{Government publications}

GN 4 in GG 5392 of 17 January 2014 (Rules of the High Court of Namibia) GN 564 in GG 5906 of 23 December 2015

Rules Relating to the Conduct of Conciliation and Arbitration Before the Labour Commissioner: Labour Act, 2007

International instruments

African Charter on Human and Peoples' Rights (1981)

International Covenant on Civil and Political Rights (1966)

Universal Declaration of Human Rights (1948)

World Trade Organization Agreement on Subsidies and Countervailing Measures (1994) 


\section{Internet sources}

Editor 2019 https://www.namibian.com.na/186617/archive-read/Stop-TheSOE-Madness-FOR-the-better-part-of

Editor 2019 Stop the SOE Madness https://www.namibian.com.na/ 186617/archive-read/Stop-The-SOE-Madness-FOR-the-better-part-of accessed 14 April 2021

Logan 2017 https://media.africaportal.org/documents/ab_r6_policy paperno39_access_to_justice_in_africa_eng.pdf Logan C 2017 Ambitious SDG Goal Confronts Challenging Realities: Access to Justice is Still Elusive for Many Africans - Afrobarometer Policy Paper No 39 https://media.africaportal.org/documents/ab_r6_ policypaperno39_access_to_justice_in_africa_eng.pdf accessed 14 April 2021

Menges 2008 https://www.namibian.com.na/48477/archive-read/Legal-Aidbattling-cash-flow-problems

Menges W 2008 Legal Aid Battling 'Cash-flow' Problems https://www.namibian.com.na/48477/archive-read/Legal-Aid-battling-cashflow-problems accessed 14 April 2021

Menges $2015 \quad \mathrm{https} / /$ www.namibian.com.na/134524/archiveread/Mediation-saving-money-and-court-time

Menges W 2015 Mediation Saving Money and Court Time https://www.namibian.com.na/134524/archive-read/Mediation-savingmoney-and-court-time accessed 14 April 2021

OECD 2010 http://www.oecd.org/competition/cartels/48379006.pdf Organisation for Economic Co-operation and Development 2010 Information Exchanges between Competitors under Competition Law http://www.oecd.org/competition/cartels/48379006.pdf accessed 29 May 2019

Oxford Dictionaries 2018 https:/en.oxforddictionaries.com/ definition/unaffordable

Oxford Dictionaries 2018 Unaffordable https://en.oxforddictionaries.com/ definition/unaffordable accessed 26 April 2018

Sieder and Sierra 2010 https://www.cmi.no/publications/file/3880indigenous-womens-access-to-justice-in-latin.pdf

Sieder R and Sierra MT 2010 Indigenous Women's Access to Justice in Latin America - Chr Michelsen Institute Working Paper No 2 
https://www.cmi.no/publications/file/3880-indigenous-womens-access-tojustice-in-latin.pdf accessed 14 April 2021

Staff Reporter 2017 https://neweralive.na/posts/namibia-reduces-povertylevels-despite-economic-challenges

Staff Reporter 2017 Namibia Reduces Poverty Levels despite Economic Challenges https://neweralive.na/posts/namibia-reduces-poverty-levelsdespite-economic-challenges accessed 14 April 2021

Stephen Date Unknown http://archive.scottish.parliament.uk/business/ committees/historic/justice1/inquiries-02/j1-lps-pdfs/lps-099.pdf

Stephen FH Date Unknown An Economic Perspective on the Regulation of Legal Service Markets http://archive.scottish.parliament.uk/business/ committees/historic/justice1/inquiries-02/j1-lps-pdfs/lps-099.pdf accessed 7 July 2017

Tjatjara 2019 https://www.namibian.com.na/184821/archive-read/JusticeMust-Have-Legs-\%E2\%80\%A6-And-Guts

Tjatjara B 2019 Justice must have Legs... and Guts https://www.namibian.com.na/184821/archive-read/Justice-Must-HaveLegs-\%E2\%80\%A6-And-Guts accessed 14 April 2021

World Bank 2018 https://data.worldbank.org/country/namibia World Bank 2018 World Bank Open Data: Namibia https://data.worldbank.org/country/namibia accessed 26 April 2018

World Bank 2018 https://data.worldbank.org/indicator/SI.POV. GINI?locations=NA

World Bank 2018 GINI Index (World Bank Estimates): Data https://data.worldbank.org/indicator/SI.POV.GINI?locations=NA accessed 6 May 2018

\section{Other}

Law Society of Namibia LSN Survey of Professional Fees 31 October 2017 (on file with the author)

\section{List of Abbreviations}

ABA

ABA Journal

ABS

ADR
American Bar Association

American Bar Association Journal alternative business structure alternative dispute resolution 


$\begin{array}{ll}\text { Beijing L Rev } & \text { Beijing Law Review } \\ \text { Cardozo L Rev } & \text { Cardozo Law Review } \\ \text { CE } & \text { Copenhagen Economics } \\ \text { CFA } & \text { contingent fee arrangements } \\ \text { CMA } & \text { Common Monetary Area } \\ \text { Denv U L Rev } & \text { Denver University Law Review } \\ \text { EC } & \text { European Commission } \\ \text { Educ Res } & \text { Educational Researcher } \\ \text { Eur J Comp Econ } & \text { European Journal of Comparative } \\ & \text { Economics } \\ \text { Fordham L Rev } & \text { Fordham Law Review } \\ \text { GDP } & \text { gross domestic product } \\ \text { GNI } & \text { gross national income } \\ \text { Harv L Rev } & \text { Harvard Law Review } \\ \text { ICCPR } & \text { International Covenant on Civil and Political } \\ & \text { Rights } \\ \text { ICT } & \text { information } \\ & \text { technology and } \\ \text { J Bus Res } & \text { Journal of Business Research } \\ \text { J Corp L } & \text { Journal of Corporation Law } \\ \text { JLA } & \text { Journal of Legal Analysis } \\ \text { J Leg Ed } & \text { Journal of Legal Education } \\ \text { J Legal Prof } & \text { Journal of the Legal Profession } \\ \text { J Polit Econ } & \text { Journal of Political Economy } \\ \text { LAC } & \text { Legal Assistance Centre } \\ \text { LCA } & \text { Legal Consumer Advocate } \\ \text { LRDC } & \text { Law Reform and Development Commission } \\ \text { LSN } & \text { Law Society of Namibia } \\ \text { NaCC } & \text { Namibian Competition Commission } \\ \text { NGO } & \text { non-government organisation } \\ \text { NLJ } & \text { Namibia Law Journal } \\ \text { NSA } & \text { Namibia Statistics Agency } \\ \text { OECD } & \text { Organisation for Economic Co-operation } \\ & \text { and Development } \\ \text { Or Rev Int'I L } & \text { Oregon Review of International Law } \\ \text { SOE } & \text { state-owned enterprise } \\ \text { Texas A\&M L Rev } & \text { Texas A\&M Law Review } \\ \text { UDHR } & \text { Universal Declaration of Human Rights } \\ \text { UNAM } & \text { University of Namibia } \\ \text { UK } & \text { United Kingdom } \\ \text { U Miami L Rev } & \text { University of Miami Law Review } \\ & \end{array}$


UNAM

US
University of Namibia

United States of America 